\title{
Effects of various additives to enhance growth performance, blood profiles, and reduce malodour emissions in growing pigs
}

\author{
W. G. Kwak ${ }^{1^{*}}$, I. H. Park ${ }^{2^{*}}$, W. Yun ${ }^{1}$, J. H. Lee ${ }^{1}$, C. H. Lee ${ }^{1}$, S. Y. Oh ${ }^{1}$, H. J. Oh ${ }^{1}$, Shudong Liu ${ }^{1}$, Y. \\ H. $\mathrm{Kim}^{3}$, J. C. Park ${ }^{3}$, G. S. Kim ${ }^{4}$ \& J. H. Cho" \\ ${ }^{1}$ Division of Food and Animal Sciences, Chungbuk National University, Cheongju, Chungbuk, Republic of Korea 286-44 \\ ${ }^{2}$ Department of Animal Science and Biotechnology, Chungnam National University, Daejeon, Republic of Korea 341-34 \\ ${ }^{3}$ Department of Swine Science, National Institute of Animal Science, Cheonan, Republic of Korea 310-00 \\ ${ }^{4}$ National Institute of Animal Science, Rural Development Administration, 1500, Kongjwipatjwiro, Iseomyeon, Wanjugun, \\ Jeollabukdo, Republic of Korea 553-65
}

(Received 23 February 2017; Accepted 12 April 2017; First published online 28 June 2017)

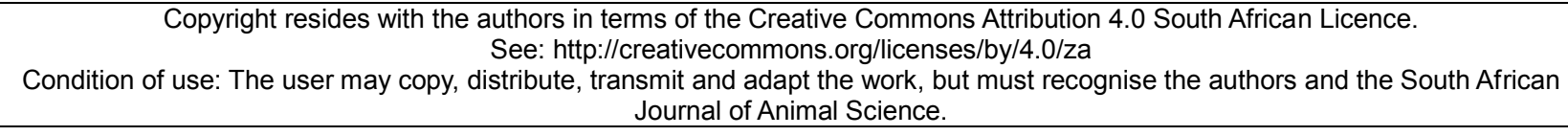

\begin{abstract}
Experiment 1 was a feeding trial in which 75 (Landrace $x$ Yorkshire) $x$ Duroc pigs with average initial bodyweight (BW) of $26 \pm 1 \mathrm{~kg}$ were used. It was assigned to three pigs/pen and five pens/treatment. Experiment 2 was a metabolic trial in which 25 (Landrace $\times$ Yorkshire) $\times$ Duroc pigs with average initial bodyweight (BW) of $36 \pm 1 \mathrm{~kg}$ were used. The basal diet consisted of maize (57.71\%), soybean meal (32.45\%), and wheat bran (5\%). Treatments consisted of i) CON (control diet); ii) OE (organic acid + essential oils) (Aviplus- ${ }^{\circledR}$ ), that is, $\mathrm{CON}+0.05 \% \mathrm{OE}$; iii) OC (organic charcoal) (Olga Black ${ }^{\circledR}$ ), that is, CON $+0.1 \% \mathrm{OC}$; iv) $\mathrm{AE}$ (anise extracts) $\left(\mathrm{RESQ}^{\circledR}\right)$, that is, $\mathrm{CON}+0.015 \% \mathrm{AE}$; and v) $\mathrm{PB}$ (probiotics) (Bonvital ${ }^{\circledR}$ ), that is, $C O N+0.1 \%$ PB. Average daily gain (ADG) and gain/feed ratio $(G: F)$ were significantly higher in the $\mathrm{OE}$ and $\mathrm{AE}$ groups than in the others. Average daily feed intake (ADFI) for $\mathrm{OE}, \mathrm{OC}$, and $\mathrm{AE}$ treatments was significantly higher than that for CON and PB treatments. Dry matter (DM) digestibility was significantly higher in $\mathrm{AE}$ than CON. Crude protein (CP) was significantly higher in $\mathrm{OE}, \mathrm{AE}$, and PB than CON. CON and other treatments did not cause significant differences in blood I-density lipoprotein (LDL), and glucose. $\mathrm{NH}_{3}$ emissions were significantly lower in all treated groups than in CON. Among the treatments, $\mathrm{NH}_{3}$ emissions were lowest in $\mathrm{OE}$ and $\mathrm{AE} . \mathrm{H}_{2} \mathrm{~S}$ emissions were significantly lower in $\mathrm{OE}, \mathrm{AE}$, and $\mathrm{PB}$ than in $\mathrm{CON}$. Among the treatments, $\mathrm{OE}$ and $\mathrm{AE}$ were most effective at reducing $\mathrm{H}_{2} \mathrm{~S}$ emissions. The emissions of volatile fatty acids (VFAs) showed no significant difference between treatments and CON. In conclusion, this experiment was shown to be more effective on growth performance, malodour emission, blood profiles, and nutrient digestibility in $\mathrm{OE}$ and $\mathrm{AE}$ than other additives.
\end{abstract}

Keywords: Digestibility, feed, influence, odour, supplementation, swine

\#Corresponding author: jinhcho@cbnu.ac.kr

* These authors contributed equally to this work

\section{Introduction}

Several compounds, such as $\mathrm{NH}_{3}$ (ammonia), $\mathrm{H}_{2} \mathrm{~S}$ (hydrogen sulfide), VFA (volatile fatty acids), and other odorous noxious gases are well known as odour-inducing substances in livestock facilities. In addition, several studies have indicated that eliminating malodours is costly and treatment for removal ranges from $\$ 0.1$ to $\$ 3 / 1000 \mathrm{~m}^{3} /$ year (Chung et al., 2004). Over the last few decades, several materials to treat this effectively have been analysed. Compounds such as essential oils, probiotics, organic acids, and charcoal have been utilized to eliminate malodours (Yan et al., 2010; Yan \& Kim, 2013; Balasubramanian et al., 2016; Chao et al., 2016).

Essential oils have been demonstrated to improve performance and reduce diarrhoea by improving immune status, intestinal ecology, and nutrient digestibility in pigs ( $\mathrm{Li}$ et al., 2012a). Furthermore, supplementation of herb extract mixtures, including those from buckwheat, thyme, curcuma, black pepper, and ginger, is not only effective in growth performance and blood cell concentration, but decreases $\mathrm{NH}_{3}$ and $\mathrm{H}_{2} \mathrm{~S}$, which are the noxious gases in faeces (Yan et al., 2011). When fed anise oil, the feed intake of sow progeny improved significantly during lactation, their growth performance increased significantly during the later nursing period, and there were positive effects on feed efficiency (Charal et al., 2016). 
Organic acids have also been used extensively as feed supplements. They can cause a drop in $\mathrm{pH}$ in the gastrointestinal tract and thereby counter microbes. They are therefore regarded as an alternative to the growth-accelerating antibiotics that are used in pigs (Canibe et al., 2005). Additionally, they play a role in reducing the harmful microbial ratio in the gastrointestinal tract (Øverland et al., 2008).

Charcoal could also increase growth rate and diet efficiency, and decrease noxious gas emissions and the number of harmful microbes in finishing pigs (Chu et al., 2013).

In preliminary attempts, these improvements were made successfully by feeding essential oils (thymol and carvacrol) or probiotics (Varel, 2002). Furthermore, probiotics were regarded as common supplements for such improvements. $\mathrm{NH}_{3}$ concentration was decreased dramatically on feeding probiotics (Philippe et al., 2011). Consequently, all these substances were demonstrated to be effective for odour reduction. Although all the substances were proved to be essential for odour elimination, there has not been an analytical comparison of them.

In this research, the authors therefore performed a comparative analysis of the substances that cause environmental and social problems associated with malodours from pigsties.

\section{Materials and methods}

Two experiments were conducted. Experiment 1 was a feeding trial. A total of 75 (Landrace $\times$ Yorkshire) $\times$ Duroc pigs with average initial BW of $26 \pm 1 \mathrm{~kg}$ were used. The experiment was assigned to three pigs/pen and five pen/treatments. The experiment was conducted over six weeks. Each pen was equipped with a one-sided stainless-steel self-feeder and a nipple drinker, which allowed pigs ad libitum access to feed and water. The basal diet consisted of maize $(57.71 \%)$, soybean meal $(32.45 \%)$, and wheat bran (5 \%) (Table 1). Treatments consisted of i) CON, control diet; ii) OE (Aviplus-S ${ }^{\circledR}$ ), CON + $0.05 \%$ $\mathrm{OE}$; iii) OC (Olga Black $\left.^{\circledR}\right), \mathrm{CON}+0.1 \% \mathrm{OC}$; iv) $\mathrm{AE}\left(\mathrm{RESQ}^{\circledR}\right), \mathrm{CON}+0.015 \% \mathrm{AE}$; and v) PB (Bonvital ${ }^{\circledR}$ ), $\mathrm{CON}+0.1 \% \mathrm{~PB}$.

Table 1 The composition of basal diet used in feeding and metabolic trial (as-fed basis).

\section{Items}

Basal diet

Ingredients, \%

Maize

57.71

Soybean meal, $44 \%$

32.45

Wheat bran

5

Soybean oil

2

Dicalcium phosphate

1.47

Limestone

0.63

Salt

0.25

DL-Methionine

0.08

L-Lysine-HCl

0.08

L-Threonine

0.03

Vitamin premix ${ }^{a}$

0.2

Mineral premix ${ }^{b}$

0.1

Calculated value: 3,277 kcal/g of metabolizable energy; $19.85 \%$ of crude protein; $0.68 \%$ of total phosphorus; $0.36 \%$ of available phosphorus; $0.66 \%$ of total calcium; $0.344 \%$ of methionine; $1.166 \%$ of lysine; $0.80 \%$ of threonine

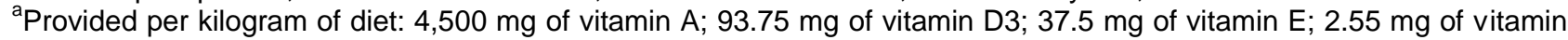
$\mathrm{K} 3 ; 3 \mathrm{mg}$ of thiamin; $7.5 \mathrm{mg}$ of riboflavin; $4.5 \mathrm{mg}$ of vitamin B6; $24 \mu \mathrm{g}$ of vitamin B12; $51 \mathrm{mg}$ of niacin; $1.5 \mathrm{mg}$ of folic acid; $0.2 \mathrm{mg}$ of biotin; and $13.5 \mathrm{mg}$ of pantothenic acid

${ }^{\mathrm{b}}$ Provided per kilogram of diet: $37.5 \mathrm{mg}$ of zinc; $37.5 \mathrm{mg}$ of manganese; $37.5 \mathrm{mg}$ of ferrum; $3.75 \mathrm{mg}$ of cuprum; $0.83 \mathrm{mg}$ of iodine; $62.5 \mathrm{mg}$ of sulphur; and $0.23 \mathrm{mg}$ of selenium

Experiment 2 was a metabolic trial. A total of 25 (Landrace $x$ Yorkshire) $x$ Duroc pigs were used with average initial BW of $36 \pm 1 \mathrm{~kg}$. The experiment was conducted in five repetitions of six days each. After five days' adaptation, a three-day period followed, during which faeces were collected. The pigs were isolated in 
$1.2 \mathrm{~m} \times 0.7 \mathrm{~m} \times 0.96 \mathrm{~m}$ stainless steel metabolic cages. Diets were fed at 08:00 and 18:00 hours. The composition of the basal diet used in experiment 2 was the same as that in Experiment 1.

In the feeding trial, feed and water intake was allowed without restriction, with the amount of feed provided and amount remaining being recorded. Pig BW was measured at the beginning and end of the experiment. Nutrient digestibility was analysed on the final day of the experiment and $0.2 \%$ chromium oxide $\left(\mathrm{Cr}_{2} \mathrm{O}_{3}\right)$ was added to the diets as an indigestible marker. After giving the chromium diet for one day, fresh excreta samples were collected for two days.

To collect blood samples from the pigs, the cervical vein artery was utilized, while pigs were fixed by a nose holder, and blood samples were collected one day before end of experiment. Faeces were collected through anal massage. After collection, fresh faeces were stored in a refrigerator at $-20^{\circ} \mathrm{C}$. In addition, $300 \mathrm{~g}$ faeces samples were collected from each pen once a week. Faeces and urine excreted on sawdust were mixed with sawdust. A total of $200 \mathrm{~g}$ mixed samples were collected and fermented. Treated samples were then stored in $4.2 \mathrm{~L}$ plastic boxes. The samples were fermented for 72 hours at $33^{\circ} \mathrm{C}$ under room conditions.

The metabolic trial enabled water intake without restriction. Daily feed intake was $4 \%$ of weight, and the remaining amount was recorded to calculate feed intake. Faeces and urine samples were withdrawn from the metabolic cages. Hydrogen chloride $(25 \mathrm{~mL}$ of $6 \mathrm{M})$ was added to a plastic box. After that, the urine samples were poured into the plastic box to prevent volatilization of urinary nitrogen. The weight of total mixed samples was measured. To further analysis, fresh urine samples were stored in a refrigerator at $-4^{\circ} \mathrm{C}$. To analyse odours, samples were stored in $4.2 \mathrm{~L}$ plastic boxes to ferment the samples. Each box contained $200 \mathrm{~g}$, namely faeces: $200 \mathrm{~g}$; and faeces + urine: $100 \mathrm{~g}+100 \mathrm{~g}$.

Growth performance in ADG, G:F, and ADFI was measured. Pig BW was measured on the initial and last days of the experiment. Individual and feed intake were recorded every day to determine ADG, ADFI, and $\mathrm{G}: \mathrm{F}$ ratio.

Before determining nutrient digestibility, faeces were dried in the drying oven $\left(70{ }^{\circ} \mathrm{C}\right)$ for 72 hours and powdered. After that, DM and CP were analysed. The apparent digestibility of DM was calculated using indirect ratio methods with the following formula:

Coefficient of apparent total tract digestibility $=\{1-[(\mathrm{Nf} \times \mathrm{Cd}) /(\mathrm{Nd} \times \mathrm{Cf})]\}$

where: $\mathrm{Nf}=$ nutrient concentration in faeces $(\% \mathrm{DM})$

$\mathrm{Nd}=$ nutrient concentration in diet $(\% \mathrm{DM})$

$\mathrm{Cf}=$ chromium concentration in faeces $(\% \mathrm{DM})$

$\mathrm{Cd}=$ chromium concentration in faeces (\% DM) (Yan \& Kim, 2011).

Nutrient digestibility was analysed as described in the AOAC (2000) procedures.

Blood samples were acquired from the cervical vein into K3EDTA vacuum tubes and Z Serum Sep Clot Activator vacuum tubes (Becton Dickinson Vacutainer System, Franklin Lakes, NJ, USA). The analysis was done intermittently at either 24 hours or 72 hours. Blood profile BUN, cholesterol, HDL, LDL, and glucose were analysed. BUN counts were determined with an automatic blood analyser (ADIVA 120, Bayer, NY) in the serum. HDL and LDL were analysed with an automatic biochemical analyser (RA-1000, Bayer Corp, Tarrytown, NY, USA).

The malodour-causing materials $\left(\mathrm{NH}_{3}, \mathrm{H}_{2} \mathrm{~S}\right.$, and VFAs) were analysed with a gas tech detection tube. Malodour analysis was achieved by dividing the three cases, namely only faecal; faecal and urine; and faecal, urine, and sawdust. After sampling, various chemicals, including $\mathrm{NH}_{3}, \mathrm{H}_{2} \mathrm{~S}$, and volatile fatty acids, were detected using Gastec GV-110S gas detection machine and tube namely, $\mathrm{NH}_{3}$ detector tube No. 3L, $\mathrm{H}_{2} \mathrm{~S}$ detector tube No. 4LL, volatile fatty acid detector tube No. 81L (Gastec Corp, Kanagawa, Japan).

Data were analysed with the GLM procedures of SAS (2008) as a randomized complete block design. The pen was used as the experimental unit. The means of the treatments were compared with Turkey's multiple range test with $P<0.05$ indicating significance.

\section{Results}

Growth performance is provided in Table 2. $A D G$ and $G: F$ were significantly higher in the $O E$ and $A E$ groups than in the others $(P<0.05)$. ADFI for $O E, O C$, and $A E$ treatments was significantly higher than those for the CON and PB treatments $(P<0.05)$.

Nutrient digestibility results are provided in Table 3 . DM digestibility was significantly higher in $A E$ than $\mathrm{CON}$, and $\mathrm{CP}$ was significantly higher in $\mathrm{OE}, \mathrm{AE}$, and $\mathrm{PB}$ than $\mathrm{CON}(P<0.05)$. 
Table 2 Effects of supplementation of various feed additives on growth performance in feeding trial

\begin{tabular}{|c|c|c|c|c|c|c|c|}
\hline Items ${ }^{1}, \mathbf{k g}$ & $\mathrm{CON}^{2}$ & $O E^{2}$ & $O C^{2}$ & $A E^{2}$ & $\mathrm{~PB}^{2}$ & S.E ${ }^{3}$ & $P$ value \\
\hline Initial BW & 27.0 & 28.3 & 28.2 & 27.0 & 29.4 & & \\
\hline Final BW & $58.6^{c}$ & $63.7^{\mathrm{a}}$ & $60.2^{\mathrm{bc}}$ & $61.7^{\mathrm{ab}}$ & $60.1^{\mathrm{bc}}$ & 0.9 & $<.0001$ \\
\hline BWG & $31.53^{b}$ & $35.4^{\mathrm{a}}$ & $32.1^{\mathrm{b}}$ & $34.7^{\mathrm{a}}$ & $30.8^{b}$ & 0.7 & $<.0001$ \\
\hline ADG, kg & $0.751^{b}$ & $0.844^{a}$ & $0.763^{b}$ & $0.826^{a}$ & $0.732^{b}$ & 0.016 & $<.0001$ \\
\hline ADFI, kg & $1.660^{b}$ & $1.693^{\mathrm{a}}$ & $1.693^{\mathrm{a}}$ & $1.711^{\mathrm{a}}$ & $1.662^{b}$ & 0.008 & $<.0001$ \\
\hline$G: F$ & $0.451^{b}$ & $0.498^{a}$ & $0.450^{b}$ & $0.484^{a}$ & $0.439^{b}$ & 0.010 & 0.0002 \\
\hline
\end{tabular}

1BW: bodyweight; BWG: bodyweight gain; ADG: average daily gain; ADFI: average daily feed intake; G : F: gain/feed.

${ }^{2} \mathrm{CON}$ : control; OE: organic acid + essential oils; OC: organic charcoal; AE: anise extracts; PB: probiotics

${ }^{3}$ Standard error

${ }^{\mathrm{abc}}$ Means in the same row with different superscripts differ $(P<0.05)$

Table 3 Effects of supplementation with feed additives on nutrient digestibility (feeding trial)

\begin{tabular}{lccccccc}
\hline Items & $\mathbf{C O N}^{1}$ & $\mathbf{O E}^{1}$ & $\mathbf{O C}^{1}$ & $\mathbf{A E}^{1}$ & PB $^{1}$ & S.E. $^{2}$ & $\boldsymbol{P}^{1}$ value \\
\hline Digestibility, \% & & & & & & & \\
Dry matter & $81.87^{\mathrm{b}}$ & $82.31^{\mathrm{ab}}$ & $82.28^{\mathrm{ab}}$ & $83.88^{\mathrm{a}}$ & $82.02^{\mathrm{ab}}$ & 0.03 & $<.0001$ \\
Crude protein & $78.70^{\mathrm{b}}$ & $79.36^{\mathrm{a}}$ & $78.78^{\mathrm{ab}}$ & $79.64^{\mathrm{a}}$ & $79.43^{\mathrm{a}}$ & 0.06 & $<.0001$
\end{tabular}

${ }_{1}^{1} \mathrm{CON}$ : control; OE: organic acid + essential oils; OC: organic charcoal; AE: anise extracts; PB: probiotics

${ }^{2}$ Standard error

${ }^{\mathrm{ab}}$ Means in the same row with different superscripts differ $(P<0.05)$

The results of blood analysis are provided in Table 4. CON and other treatments did not have significant differences in blood profiles of parameters such as BUN, cholesterol, HDL, LDL, or glucose $(P$ $>0.05$ ).

Malodour emissions in the feeding trial are provided in Table 5. $\mathrm{NH}_{3}$ emissions were significantly lower in the treated groups than in $\mathrm{CON}(P<0.05) . \mathrm{H}_{2} \mathrm{~S}$ emissions were significantly lower in $\mathrm{OE}, \mathrm{AE}$, and $\mathrm{PB}$ than in CON $(P<0.05)$. The emissions of VFAs showed no significant differences between treatments and CON.

Table 4 Effects of supplementation of feed additives on blood profiles in feeding trial

\begin{tabular}{|c|c|c|c|c|c|c|c|}
\hline Items $^{1}, \mathrm{mg} / \mathrm{dL}$ & $\mathrm{CON}^{2}$ & $O E^{2}$ & $O C^{2}$ & $A E^{2}$ & $\mathrm{~PB}^{2}$ & S.E $^{3}$ & $P$ value \\
\hline BUN & 13 & 12 & 11 & 13 & 11 & 1 & 0.7330 \\
\hline Cholesterol & 101 & 104 & 99 & 102 & 97 & 6 & 0.9139 \\
\hline $\mathrm{HDL} / \mathrm{C}$ & 54 & 48 & 48 & 52 & 46 & 2 & 0.2065 \\
\hline LDL/C & 49 & 57 & 54 & 52 & 52 & 4 & 0.6884 \\
\hline Glucose & 96 & 97 & 100 & 99 & 86 & 6 & 0.4606 \\
\hline
\end{tabular}

${ }^{1} \mathrm{BUN}$ : blood urea nitrogen; HDL/C: high-density lipoproteins/cholesterol; LDL/C: low-density lipoprotein/cholesterol

${ }^{2} \mathrm{CON}$ : control; OE: organic acid + essential oils; OC: organic charcoal; AE: anise extracts; PB: probiotics

${ }^{3}$ Standard error

The malodour emission findings in the metabolic trial are provided in Tables 6 and $7 . \mathrm{NH}_{3}$ emissions in Table 6 were significantly higher in CON than in other treatment groups $(P<0.05)$. Among the treatments, $\mathrm{NH}_{3}$ emissions were lowest in $\mathrm{OE}$ and $\mathrm{AE} . \mathrm{H}_{2} \mathrm{~S}$ emissions were significantly lower than $\mathrm{CON}$ in $\mathrm{OE}$ and $\mathrm{AE}$ treatments $(P<0.05)$. Emissions of VFAs did not differ significantly between the treatments and CON $(P$ 
$>0.05$ ).

$\mathrm{NH}_{3}$ emissions in Table 7 were significantly lower in the treatments with additives than in CON ( $P$ $<0.05)$. However, $\mathrm{H}_{2} \mathrm{~S}$ and VFA emissions did not differ significantly between the treatments and CON.

Table 5 Effects of supplementation with feed additives on odour emissions from faecal, urine and sawdust mixture in feeding trial

\begin{tabular}{|c|c|c|c|c|c|c|c|}
\hline Items ${ }^{1}, \mathrm{ppm}$ & $\mathrm{CON}^{2}$ & $O E^{2}$ & $O C^{2}$ & $A E^{2}$ & $\mathrm{~PB}^{2}$ & S.E. ${ }^{3}$ & $P$ value \\
\hline $\mathrm{NH}_{3}$ & $12.5^{a}$ & $6.2^{\mathrm{b}}$ & $8.3^{b}$ & $5.9^{\mathrm{b}}$ & $7.2^{b}$ & 1.3 & 0.001 \\
\hline $\mathrm{H}_{2} \mathrm{~S}$ & $113^{\mathrm{a}}$ & $78^{\mathrm{b}}$ & $91^{\mathrm{ab}}$ & $80^{b}$ & $87^{b}$ & 8 & 0.025 \\
\hline VFA & 0.1 & 0.4 & 0.4 & 0.2 & 0.4 & 0.2 & 0.339 \\
\hline
\end{tabular}

${ }^{1} \mathrm{NH}_{3}$ : ammonia; $\mathrm{H}_{2} \mathrm{~S}$ : Hydrogen sulfide; VFA: volatile fatty acids

${ }^{2} \mathrm{CON}$ : control; OE: organic acid + essential oils; OC: organic charcoal; AE: anise extracts; PB: probiotics

${ }^{3}$ Standard error

${ }^{\mathrm{ab}}$ Means in the same row with different superscripts differ $(P<0.05)$

Table 6 Effects of supplementation with feed additives on faecal odour emissions in metabolic trial

\begin{tabular}{|c|c|c|c|c|c|c|c|}
\hline Items ${ }^{1}, \mathrm{ppm}$ & $\mathrm{CON}^{2}$ & $O E^{2}$ & $O C^{2}$ & $A E^{2}$ & $\mathrm{~PB}^{2}$ & S.E. ${ }^{3}$ & $P$ value \\
\hline $\mathrm{NH}_{3}$ & $1.65^{a}$ & $0.5^{\mathrm{b}}$ & $0.8^{\mathrm{b}}$ & $0.5^{\mathrm{b}}$ & $0.7^{\mathrm{b}}$ & 0.2 & 0.0110 \\
\hline $\mathrm{H}_{2} \mathrm{~S}$ & $92.5^{a}$ & $59.0^{\mathrm{b}}$ & $77.0^{\mathrm{ab}}$ & $60.8^{\mathrm{b}}$ & $73.5^{\mathrm{ab}}$ & 8.3 & 0.0471 \\
\hline VFA & 0.9 & 1.0 & 1.1 & 0.5 & 0.9 & 0.4 & 0.7034 \\
\hline
\end{tabular}

${ }^{T} \mathrm{NH}_{3}$ : ammonia; $\mathrm{H}_{2} \mathrm{~S}$ : Hydrogen sulfide; VFA: volatile fatty acids

${ }^{2} \mathrm{CON}$ : control; OE: organic acid + essential oils; OC: organic charcoal; AE: anise extracts; PB: probiotics

${ }^{3}$ Standard error

${ }^{\mathrm{ab}}$ Means in the same row with different superscripts differ $(P<0.05)$

Table 7 Effects of supplementation with feed additives on faecal and urine odour emissions in metabolic trial

\begin{tabular}{lccccccc}
\hline Items & \\
\end{tabular}

${ }^{1} \mathrm{NH}_{3}$ : ammonia; $\mathrm{H}_{2} \mathrm{~S}$ : Hydrogen sulfide; VFA: volatile fatty acids

${ }^{2} \mathrm{CON}$ : control; OE: organic acid + essential oils; OC: organic charcoal; AE: anise extracts; PB: probiotics

${ }^{3}$ Standard error

${ }^{\mathrm{ab}}$ Means in the same row with different superscripts differ $(P<0.05)$

\section{Discussion}

In this study, it was demonstrated that most of the additives $O E, O C$, and $A E$ enhanced the growth performance. Among them, essential oils proved best in terms of growth performance. In addition, the values of BW, ADG, ADFI, and G : F were improved significantly by dietary supplementation with $O E$ and $A E$. In a previous study, supplementation of vanillin (essential oil) increased feed intake and growth performance (Gallage et al., 2014). In addition, the essential oils were beneficial in increasing feed intake, digestive secretions, and immune stimulation, and enhancing anti-bacterial, antiviral, and antioxidant characteristics (Wenk, 2003).

The effects of $A E$ on nutrient digestibility and $D M$ digestibility were statistically significant. Furthermore, the $\mathrm{OE}, \mathrm{AE}$, and PB treatments led to statistically significant changes in the digestibility of $\mathrm{CP}$. In another 
study, supplementing the diet with an essential oil increased the digestibility of CP and amino acids (Maenner et al., 2011). In the treatment, OE increased the growth performance and nutrient digestibility in finishing pigs. Moreover, other studies have suggested that essential oils improved growth performance, measured in terms of BW, ADG, ADFI, and $G: F$, because they stimulated intestinal enzymes, leading to increased nutrient digestibility, balance of microbiota, and feed intake (Huang et al., 2010; Li et al., 2012b; Lan et al., 2016). Additionally, a previous study revealed that a microencapsulated feed containing organic acids and essential oil added to finishing pig diet could increase growth performance, nutrient digestibility of DM, and energy (Cho et al., 2014). More recently, lactic acid bacteria were proved to be effective in this regard. Enterococcus faecium DSM 7134, a lactic acid bacterium, showed beneficial effects on the apparent ileal digestibility of CP and amino acid, and on intestinal health (Zhang \& Kim, 2015).

In this study, blood profiles did not differ significantly in the treatments. In addition, in a previous study, some immunological substances in the blood were increased, but the characteristics of BUN, LDL, and HDL were not altered significantly (Cho et al., 2006). Furthermore, sows increased some immune substances in serum, and ADFI and ADG of growth performance were enhanced in the sow and nursing piglets (Wang et al., 2015).

The current study also demonstrated an excellent effect on growth performance and reduction of malodour. In this study, $\mathrm{OE}$ and $\mathrm{AE}$ showed a similar effect in reducing the production of $\mathrm{H}_{2} \mathrm{~S}$. The emission of $\mathrm{NH}_{3}$ and thus malodour was decreased in the treatment with essential oil, and in the treatment with a combination of $\mathrm{PB}$ and $\mathrm{OC}$. However, $\mathrm{H}_{2} \mathrm{~S}$ emission was not affected significantly by the essential oil treatment $(P<0.05)$. The production of VFAs was not significantly different $(P>0.05)$. However, in a previous study it was shown that the blend of $O A$ and nature identical compounds included in OE increased its antimicrobial effect, leading to a reduction in the concentration of VFAs (Grilli et al., 2010). Besides, the decrease ileum digestibility promoted by essential oil supplementation was caused by instantaneous decrease in the caecal VFA concentrations, especially in diets containing 18\% CP (Manzanilla et al., 2009). Thus, the effect of reduction of the VFAs by essential oils has already been demonstrated. Therefore, there is a need for further research into the effects of essential oils on the concentration of VFAs.

In summary, essential oil was most effective among the additives. It is potentially good at reducing malodour. Moreover, the animal husbandry industry has recently faced problems in using antibiotics. The results of previous studies suggest that essential oils could function as a replacement for antibiotics. The volatile compounds in essential oils suppress the growth of bacterial pathogens, could be a source of metabolites with antibacterial activity, and could be used as alternatives to antibiotic therapy against these pathogens (Rodrigues et al., 2009). In the near future, essential oils are expected to be used as a good alternative for reducing malodours and improving the growth performance of pigs.

\section{Conclusions}

In this study, adding various additives (OE, OC, $\mathrm{AE}$, and $\mathrm{PB}$ ) to the diets of finishing pigs was demonstrated to be effective in removing malodour and improving growth performance. The results were that the treatments with additives, in terms of $\mathrm{NH}_{3}$ and $\mathrm{H}_{2} \mathrm{~S}$ production were significantly lower than the CON except for some $\mathrm{OC}$ items. Among them, $\mathrm{OE}$ and $\mathrm{AE}$ had an excellent effect on odor reduction. Consequently, in this experiment, $\mathrm{OE}$ and $\mathrm{AE}$ were shown to be more effective in growth performance, nutrient digestibility and malodour emission than other additives.

\section{Acknowledgments}

This work was carried out with the support of Cooperative Research Program for Agriculture Science \& Technology Development (Project No. PJ012067) Rural Development Administration, Republic of Korea.

\section{Authors' Contributions}

J.H. Cho oversaw project design. W. Yun and Shudong Liu supervised the course of the study. J.H. Lee, C.H. Lee, S.Y. Oh, H.J. Oh, I.H. Park, Y.H. Kim, J.C. Park, and G.S. Kim oversaw sample collecting and participated in results and statistics. W.G. Kwak wrote the manuscript and revised it.

\section{Conflict of Interest Declaration}

The authors declare that they have no conflict of interest.

\section{References}

AOAC, 2000. Official methods of analysis, 17th ed. Assoc. Off. Anal. Chem, Inc. Gaithersburg, MD, USA.

Balasubramanian, B., Park, J.W. \& Kim, I.H., 2016. Evaluation of the effectiveness of supplementing micro-encapsulated organic acids and essential oils in diets for sows and suckling piglets. Ital. J. Anim. Sci. 15, 626-633.

Canibe, N., Højberg, O., Højsgaard, S. \& Jensen, B.B., 2005. Feed physical form and formic acid addition to the feed affect the gastrointestinal ecology and growth performance of growing pigs. J. Anim. Sci. 83, 1287-1302.

Chao, N.V., Thong, H.T., QuynhChau, H.L., Tam, V.T. \& Rui, Z., 2016. Effects of charcoal and wood vinegar dietary 
supplementation to diarrhea incidence and faecal hydrogen sulfide emissions in pigs. Int. J. Sci. Res. Pub. 6, 707713.

Charal, J.W., Bidner, T.D., Southern, L.L.\& Lavergne, T.A., 2016. Effect of anise oil fed to lactating sows and nursery pigs on sow feed intake, piglet performance, and weanling pig feed intake and growth performance. Prof. Anim. Sci. 32, 99-105.

Cho, J.H., Song, M.H. \& Kim, I.H., 2014. Effect of microencapsulated blends of organic acids and essential oils supplementation on growth performance and nutrient digestibility in finishing pigs. Rev. Colomb. Cienc. Pec. 27, 264-272.

Cho, J.H., Chen, Y.J., Min, B.J., Kim, H.J., Kwon, O.S., Shon, K.S., Kim, I.H., Kim, S.J. \& Asamer, A., 2006. Effects of essential oils supplementation on growth performance, IgG concentration and fecal noxious gas concentration of weaned pigs. Asian-Aust. J. Anim. Sci. 19, 80-85.

Chu, G.M., Kim, J.H., Kim, H.Y., Ha, J.H., Jung, M.S., Song, Y., Cho, J.H., Lee, S.J., Ibrahim, R.I.H., Lee, S.S. \& Song, Y.M., 2013. Effects of bamboo charcoal on the growth performance, blood characteristics and noxious gas emission in fattening pigs. J. Appl. Anim. Res. 41, 48-55.

Chung, Y.-C., Lin, Y.-Y. \& Tseng, C.-P., 2004. Operational characteristics of effective removal of $\mathrm{H}_{2} \mathrm{~S}$ and $\mathrm{NH}_{3} \mathrm{waste}$ gases by activated carbon biofilter. J. Air Waste Manag. Assoc. 54, 450-458.

Gallage, N.J., Hansen, E.H., Kannangara, R., Olsen, C.E., Motawia, M.S., Jørgensen, K., Holme, I., Hebelstrup, K., Grisoni, M. \& Møller, B.L., 2014. Vanillin formation from ferulic acid in Vanilla planifolia is catalysed by a single enzyme. Nat. Commun. 5, 4037.

Grilli, E., Messina, M.R., Tedeschi, M. \& Piva, A., 2010. Feeding a microencapsulated blend of organic acids and nature identical compounds to weaning pigs improved growth performance and intestinal metabolism. Livest. Sci. 133, 173-175

Huang, Y., Yoo, J.S., Kim, H.J., Wang, Y., Chen, Y.J., Cho, J.H. \& Kim, I.H., 2010. Effects of dietary supplementation with blended essential oils on growth performance, nutrient digestibility, blood profiles and fecal characteristics in weanling pigs. Asian-Aust. J. Anim. Sci. 23, 607-613.

Lan, R.X., Li, T.S. \& Kim, I.H., 2016. Effects of essential oils supplementation in different nutrient densities on growth performance, nutrient digestibility, blood characteristics and faecal microbial shedding in weaning pigs. Anim. Feed Sci. Technol. 214, 77-85.

Li, P., Piao, X., Ru, Y., Han, X., Xue, L. \& Zhang, H., 2012a. Effects of adding essential oil to the diet of weaned pigs on performance, nutrient utilization, immune response and intestinal health. Asian-Aust. J. Anim. Sci. 25, 1617-1626.

Li, S.Y., Ru, Y.J., Liu, M., Xu, B., Péron, A. \& Shi, X.G., 2012b. The effect of essential oils on performance, immunity and gut microbial population in weaner pigs. Livest. Sci. 145, 119-123.

Maenner, K., Vahjen, W. \& Simon, O., 2011. Studies on the effects of essential-oil-based feed additives on performance, ileal nutrient digestibility, and selected bacterial groups in the gastrointestinal tract of piglets1. J. Anim. Sci. 89, 2106-2112.

Manzanilla, E.G., Pérez, J.F., Martín, M., Blandón, J.C., Baucells, F., Kamel, C. \& Gasa, J., 2009. Dietary protein modifies effect of plant extracts in the intestinal ecosystem of the pig at weaning1. J. Anim. Sci. 87, 2029-2037.

Øverland, M., Kjos, N.P., Borg, M., Skjerve, E. \& Sørum, H., 2008. Organic acids in diets for entire male pigs: Effect on skatole level, microbiota in digesta, and growth performance. Livest. Sci. 115, 169-178.

Philippe, F.-X., Cabaraux, J.F. \& Nicks, B., 2011. Ammonia emissions from pig houses: Influencing factors and mitigation techniques. Agric. Ecosyst. Environ. 141, 245-260.

Rodrigues, F.F.G., Costa, J.G.M. \& Coutinho, H.D.M., 2009. Synergy effects of the antibiotics gentamicin and the essential oil of Croton zehntneri. Phytomedicine 16, 1052-1055.

Statistical Analysis Systems (SAS). 2008. SAS/STAT User's guide, Release 9.1.3. SAS Institute Inc, Cary, North Carolina, USA.

Varel, V.H., 2002. Carvacrol and thymol reduce swine waste odour and pathogens: stability of oils. Curr. Microbiol. 44, 38-43.

Wang, G.Y., Yang, C., Yang, Z., Yang, W., Jiang, S., Zhang, G., Guo, Y. \& Wei, M., 2015. Effects of dietary star anise (Illicium verum Hook f) supplementation during gestation and lactation on the performance of lactating multiparous sows and nursing piglets. Anim. Sci. J. 86, 401-407.

Wenk, C., 2003. Herbs and botanicals as feed additives in monogastric animals. Asian-Aust. J. Anim. Sci. 16, 282-289.

Yan, L. \& Kim, I., 2011. Effect of dietary grape pomace fermented by Saccharomyces boulardii on the growth performance, nutrient digestibility and meat quality in finishing pigs. Asian-Aust. J. Anim. Sci. 24, 1763-1770.

Yan, L. \& Kim, I.H., 2013. Effect of probiotics supplementation in diets with different nutrient densities on growth performance, nutrient digestibility, blood characteristics, faecal microbial population and faecal noxious gas content in growing pigs. J. Appl. Anim. Res. 41, 23-28.

Yan, L., Meng, Q.W. \& Kim, I.H., 2011. The effect of an herb extract mixture on growth performance, nutrient digestibility, blood characteristics and faecal noxious gas content in growing pigs. Livest. Sci. 141, 143-147.

Yan, L., Wang, J.P., Kim, H.J., Meng, Q.W., Ao, X., Hong, S.M. \& Kim, I.H., 2010. Influence of essential oil supplementation and diets with different nutrient densities on growth performance, nutrient digestibility, blood characteristics, meat quality and faecal noxious gas content in grower-finisher pigs. Livest. Sci. 128, 115-122.

Zhang, Z.F. \& Kim, I.H., 2015. Effects of Enterococcus faecium DSM 7134 supplementation in different energy and CP density diets on ileal amino acid digestibility and intestinal shedding of lactobacilli and Escherichia coli in finishing pigs. Anim. Feed Sci. Technol. 201, 115-119. 